Vol. 5, No. 1, 2020

\title{
RESEARCH OF INTERRELATIONS BETWEEN METEOFACTORS AND WATER LEVEL FLUCTUATION IN LAKE SVITIAZ
}

\author{
Oleksandr Moroz, Zoryana Tartachynska, Tetiana Korliatovych, Ivan Pokotylo \\ Lviv Polytechnic National University, \\ Department of Geodesy, \\ 12, S. Bandery Str., Lviv, 79013, Ukraine \\ ztartachynska@yahoo.com,tetiasek@gmail.com
}

https://doi.org/10.23939/ep2020.01.039

Received: 03.02.2020

(C) Moroz O., Tartachynska Z., Korliatovych T., Pokotylo I., 2020

\begin{abstract}
The interrelations between the air temperature and humidity, the amount of precipitation and the water level fluctuations have been investigated based on longterm observations at the permanent water gauge of Lake Svitiaz. The average values of the correlation coefficients between the meteorological factors and the water level for the period of 1985-2019 are calculated.
\end{abstract}

Key words: surface water, water level gauge, correlation coefficient, meteorological factors.

\section{Introduction}

The group of Shatsk Lakes is one of the largest in Europe, and it numbers 23 lakes with a total area of about 7 thousand hectares. Shatsk Lakes are located between the rivers of the Western Bug and the Pripyat. The waters of Shatsk Lakes replenish the Baltic and the Black Seas basins via the rivers of the Western Bug, the Vistula, the Prypiat, and the Dnieper. All lakes are characterized by slow water exchange and belong to reservoirs with a small and medium-specific water exchange. The largest of them are Svitiaz (2622 ha, maximum depth $-58.4 \mathrm{~m}$, average $-6.9 \mathrm{~m}$ ), Pulemetske (1568 ha, maximum depth $19.2 \mathrm{~m}$, average - 4.1), Luky (673 ha, maximum depth $3.2 \mathrm{~m}$, average $-2.1 \mathrm{~m}$ ), Lutsymer (430 ha, maximum depth $-11.0 \mathrm{~m}$, average $-4.4 \mathrm{~m}$ ) and Pisochne (187 ha, maximum depth $-16.2 \mathrm{~m}$, average $-6.9 \mathrm{~m}$ ). Most lakes are interconnected by reclamation or natural channels. The most common types of lakes are of glacial and karst origin. The largest lakes, such as Svitiaz, Pulemetske, Luky, Pisochne, are of karst origin. The water level in the lakes of the karst type is generally stable, as they are fed not only by precipitation and groundwater but by the water of the lower cretaceous horizons as well. Some lakes are located among the bog massives and are replenished only at the expense of atmospheric precipitation and groundwater $[1,2]$.

To preserve the lake complex, the unique nature, the rare species of animals and plants, as well as to use the territory for the restoration of people's health and their recreation, Shatsk Natural National Park was created in 1983. Since 1999, the area of the park has been 48,977 hectares. Most of the park is occupied by forests (27100 ha $-55.3 \%)$, meadows (3600 ha $-7.3 \%)$, swamps $(1300$ ha $-2.7 \%)$, reservoirs (6900 ha $-14.1 \%)$. [3]

In 2002, the park was granted the status of the biosphere reserve "Shatskyi" by UNESCO. In 2012, the International Biosphere Reserve "Western Polissia" was created under the UNESCO program, which included biospheric reserves "Shatskyi" (Ukraine), "Western Polissia" (Poland), and "Prybuzke Polissia" (Belarus). The Trans-Border Biosphere Reserve "Western Polissia" is one of the main objects of landscape and biological diversity conservation not only within the Polissia but also in Central and Eastern Europe. [2]

Many domestic and foreign scientists devoted their works to the comprehensive research of the Polissia lakes, namely V. Tymchenko, V. Pohrebennyk [4], H. Prots, L. Ilin [5], O.Diatel [6], N. Karpenko [7], V. Mokryi [8], S. Kutovyi [9], N. Khomik [1], St. Lencewicz, B. Krygowski, J. Kondracki and others.

\section{Experimental part}

To solve the ecological, hydrological and engineering tasks, as well as to create the high-rise basis of the GIS, in 2015, the teachers of the Department of Geodesy of Lviv Polytechnic National University began their work on the construction of a geodetic foundation in this territory. During 2015-2017, high-altitude polygons around the lakes Pisochne and Svitiaz were created by the III class 
of leveling. The polygon consists of the existing leveling points, and additionally mounted marks. The scheme of polygons is shown in Fig.1. The length of the polygon around Lake Pisochne is $26.8 \mathrm{~km}$, and the number of points is 14 . The length of the polygon around Lake Svitiaz is $32.6 \mathrm{~km}$. This polygon consists of 12 points. It is planned to expand the geodetic network to the entire territory of the Trans-Border biosphere reserve "Western Polissia" by adding three more polygons. Besides, all the lakes situated in the territory of the reserve have to be equipped by the water-level gauges to continue hydrologic monitoring. This will enable us to determine the absolute altitudes of the water level of the lakes and rivers, ground water-bearing horizon, and their fluctuations. [10]
The observation over relative fluctuations in the levels of surface, ground, and underground waters has been conducted in the territory of the park for more than 30 years. [9] The permanent water level gauge is equipped only on Lake Svitiaz. The meteorological station operates in the village of Svityaz. After the survey of SNPP territory, the location of 6 pressure wells and 15 ground wells was defined. Additionally, the temporal water-level gauges were installed on lakes Pisochne, Moshne, Krymne, Peremut, Somenets, Lutsymer, Chorne Velyke, Pulemetske, and Ostrivjanske. Since April 2016, monthly monitoring of the water level in the lakes has been carried out. The water-level gauge on Lake Svitiaz and temporary water-level gauges, pressure wells, and ground wells were united into a single State system of heights $[11,12]$.

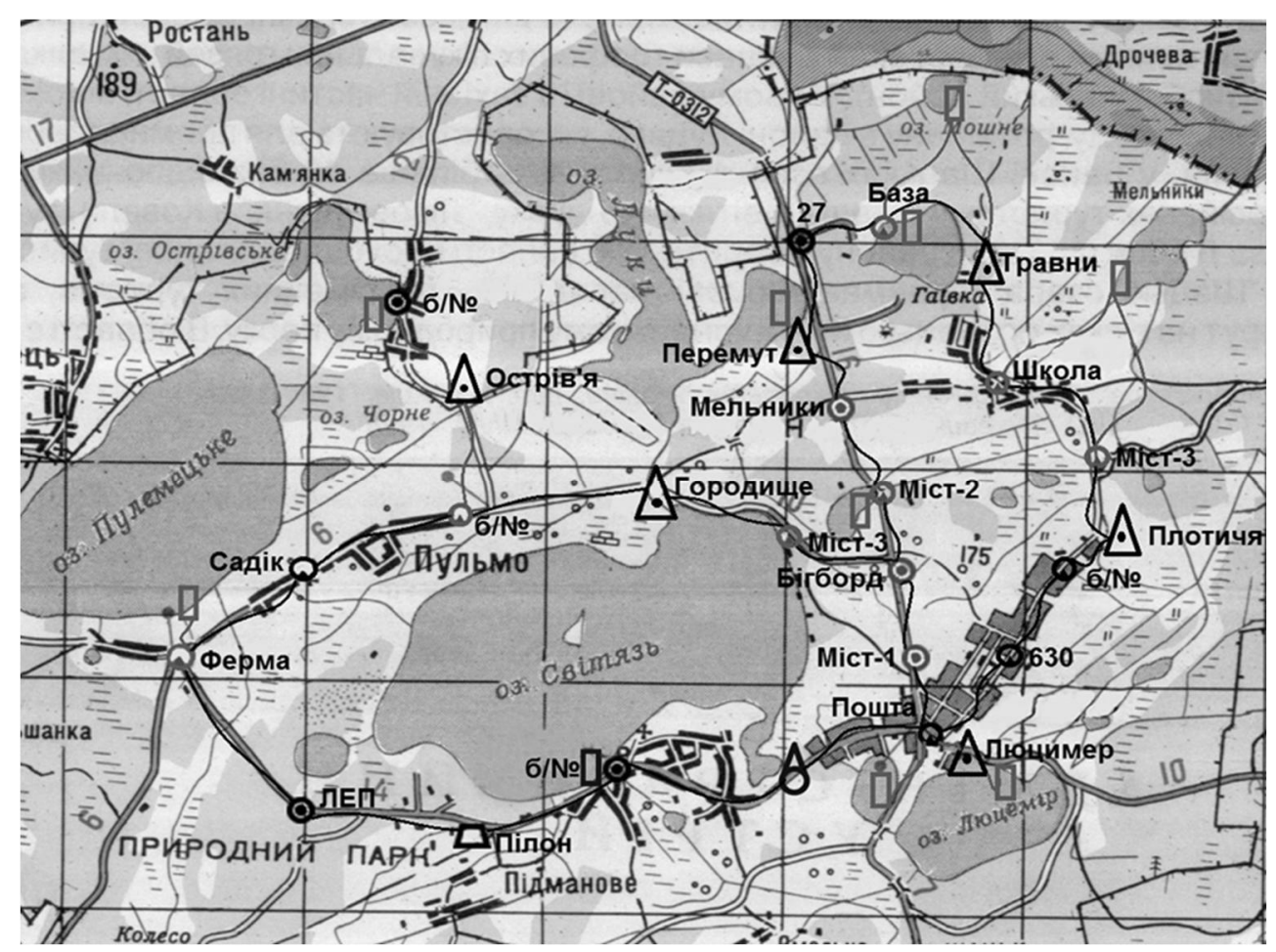

Fig. 1. Scheme of high-altitude base on the territory of SNNP

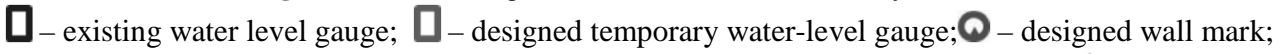

$\boldsymbol{O}$ - existing ground mark; $\mathbf{O}$ - designed wall mark; $\boldsymbol{O}$ - existing wall mark; $\mathbf{\boldsymbol { O }}$-well.

\section{Results and Discussion}

To study the inter-relations between the water level fluctuations, and the air temperature, air humidity, and the amount of precipitation, the results of long-term observations over the permanent waterlevel gauge in Lake Svitiaz were used. During 1985-2019, the average value of the correlation coefficient between the temperature and the water level was 0.19. The graphs of the average annual temperature and the water level fluctuations for the investigated period are presented in Fig. 2.
The investigation of seasonal (monthly) fluctuations of the water level, from 2006 to 2019, was carried out. The correlation coefficient between the average monthly temperature and the water level in Lake Svitiaz, according to the data of 2016, was 0.55. The maximum correlation value was calculated, which is 0.96 at a shift of 2 months. This is clearly shown in Fig. 3. The same analysis was performed according to the discrete data of 2017 in other lakes of Shatsk National Nature Park as during this period we were conducting monthly monitoring of the water level of Shatsk Lakes. In all the studied lakes the maximum correlation is observed with 
the bias of 3 months. For example, for Lake Pisochne, the correlation coefficient is 0.92 , for Lake Krymne - 0.94, for Lake Moshne - 0.96. It was found that the delay between the change in the water level and the temperature is an average of 2-3 months. According to observations in 2019, the correlation coefficient between the water level in Lake Svitiaz and the air temperature is -0.27 , and the maximum correlation coefficient at a shift of 4 months is 0.84 . This indicates an anomaly compared to other years. To determine the relationship between the level of water and the amount of precipitation averaged over the year, the data for the period of 1985-2019 was used. The average value of the correlation coefficient between the water level and the amount of precipitation for this period is 0.39 . The graph is presented in Fig. 4. The average value of the correlation coefficient between the amount of precipitation and the level of water for the period of 1985-2019, with a delay of one year, is 0.61. This is illustrated by the graph in Fig. 5. Such a correlation coefficient indicates a much greater correlation between the water level and the last year precipitation.

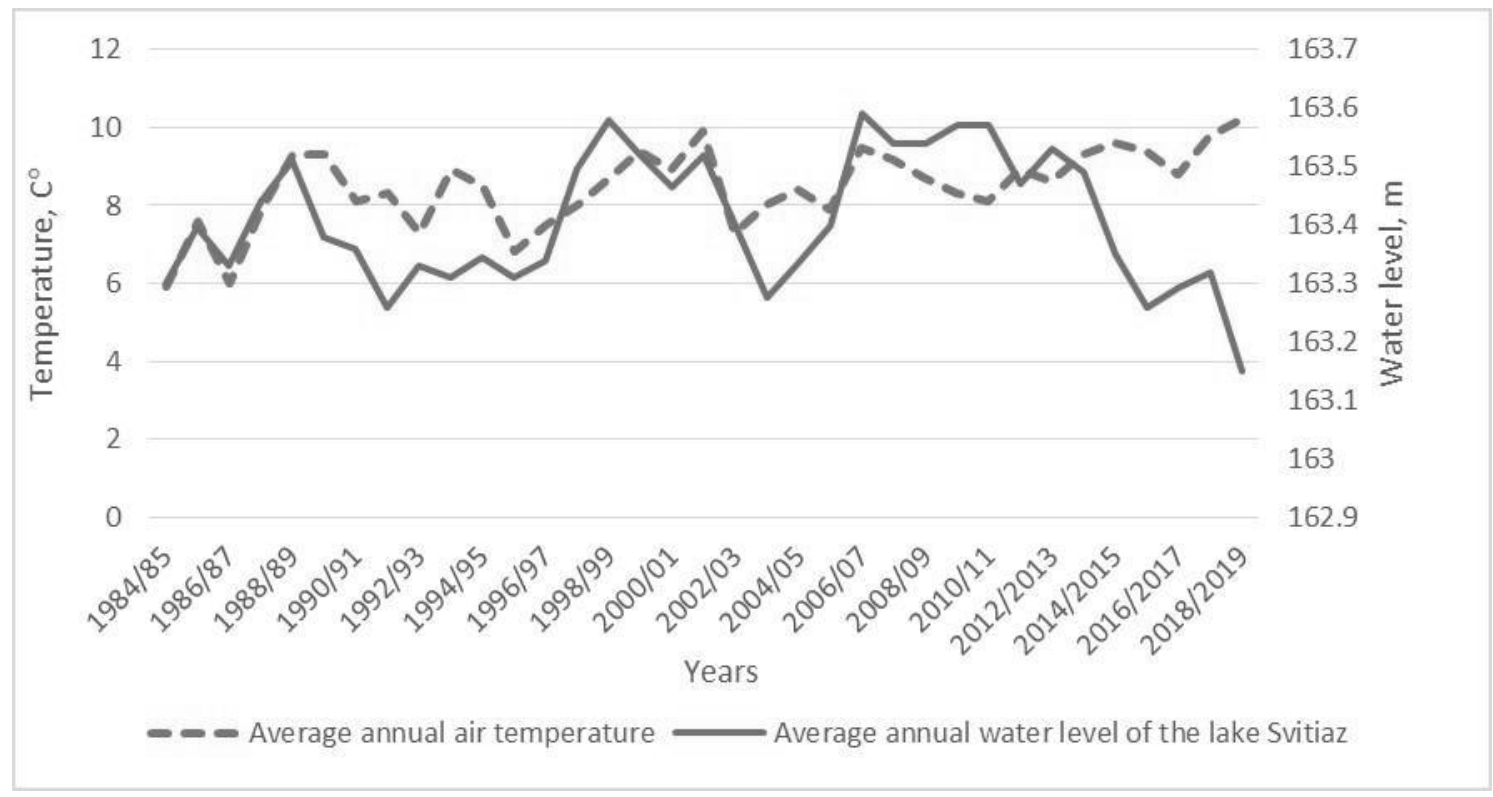

Fig. 2. Dependence between average annual temperature of air and the water level in the Lake Svitiaz

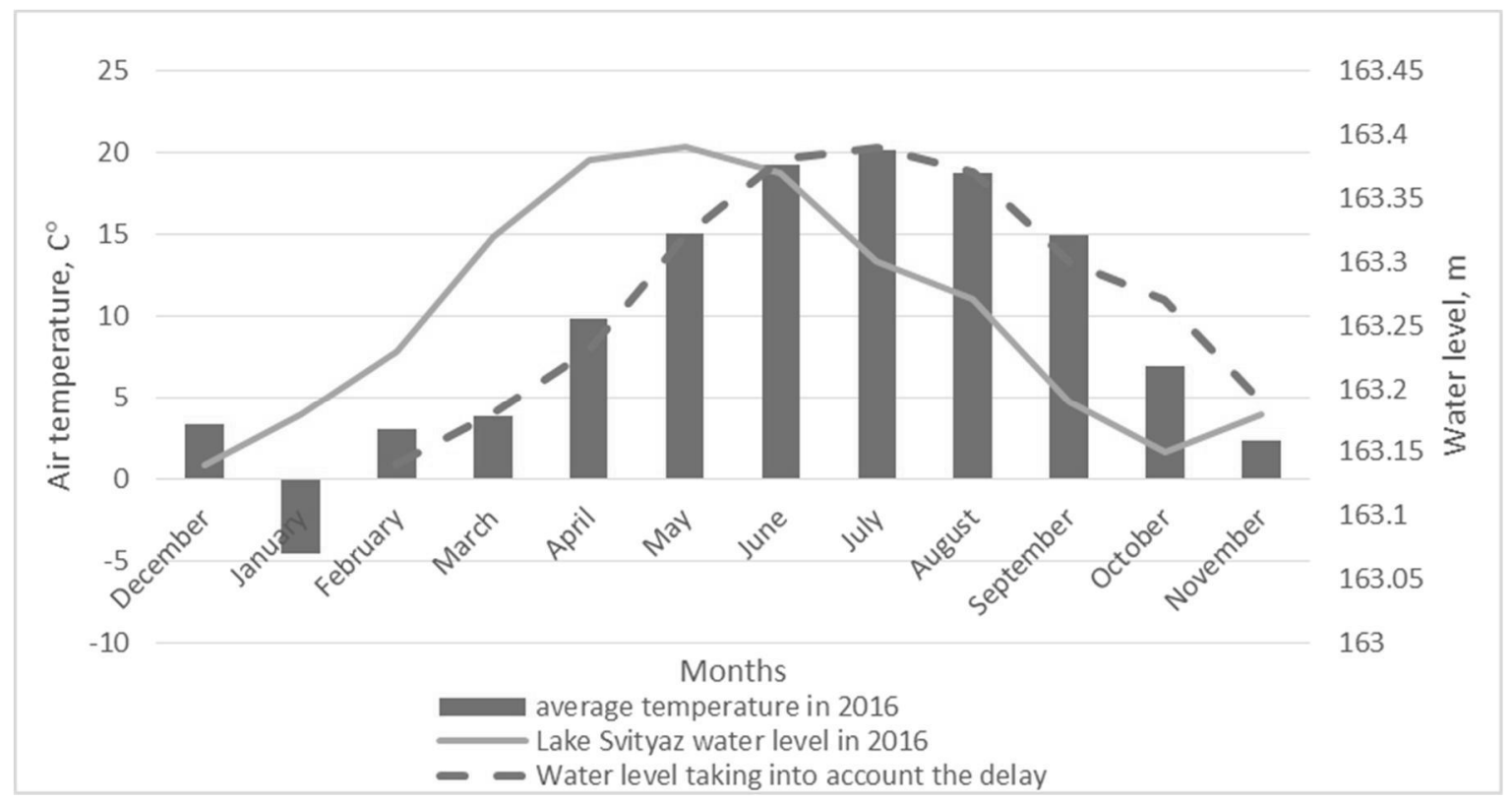

Fig. 3. Dependence between average monthly air temperature and the water level in Lake Svitiaz according to 2016 data 


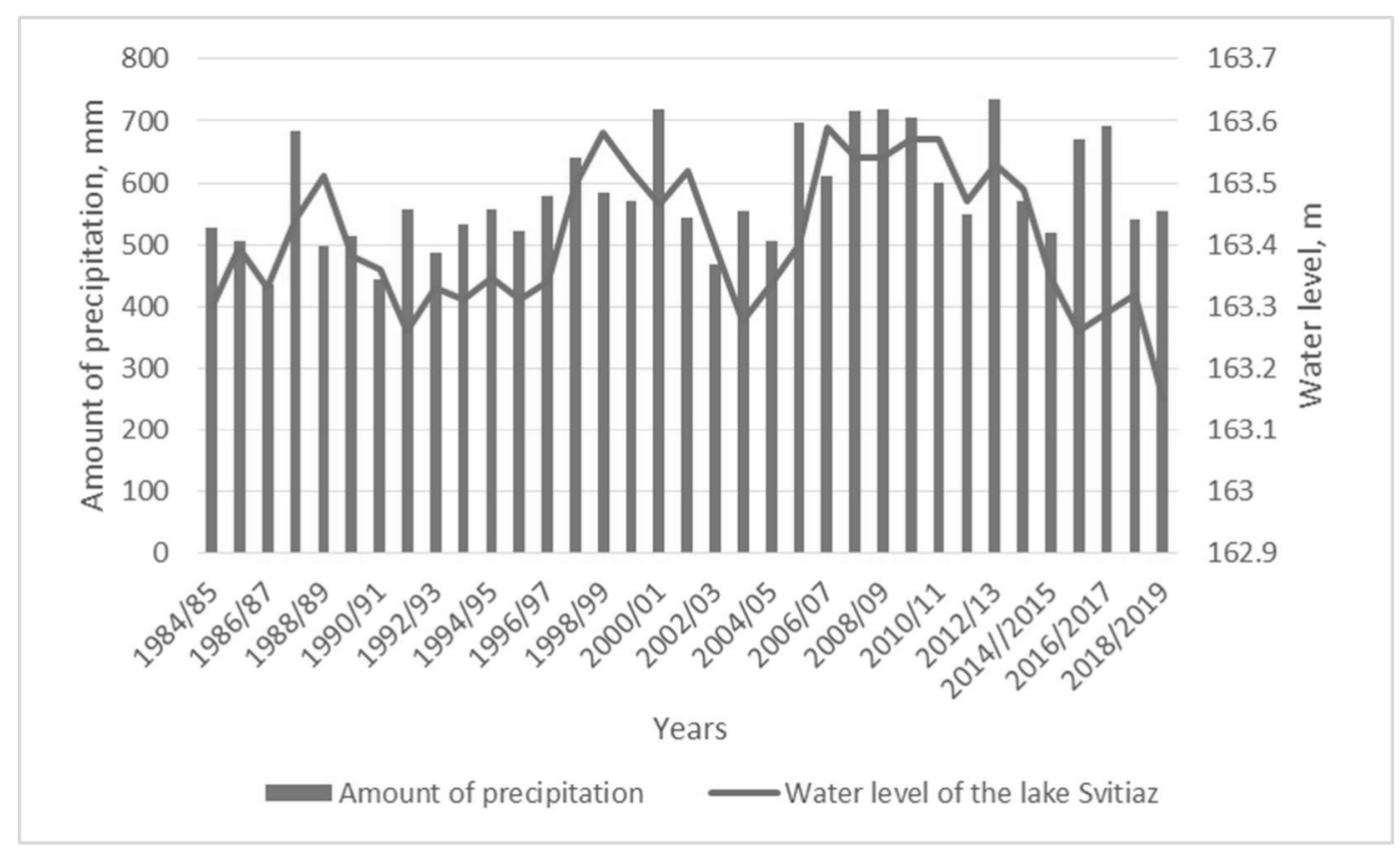

Fig. 4. Dependence between the averaged amount of precipitations and the water level in Svitiaz Lake for the period 1985-2019

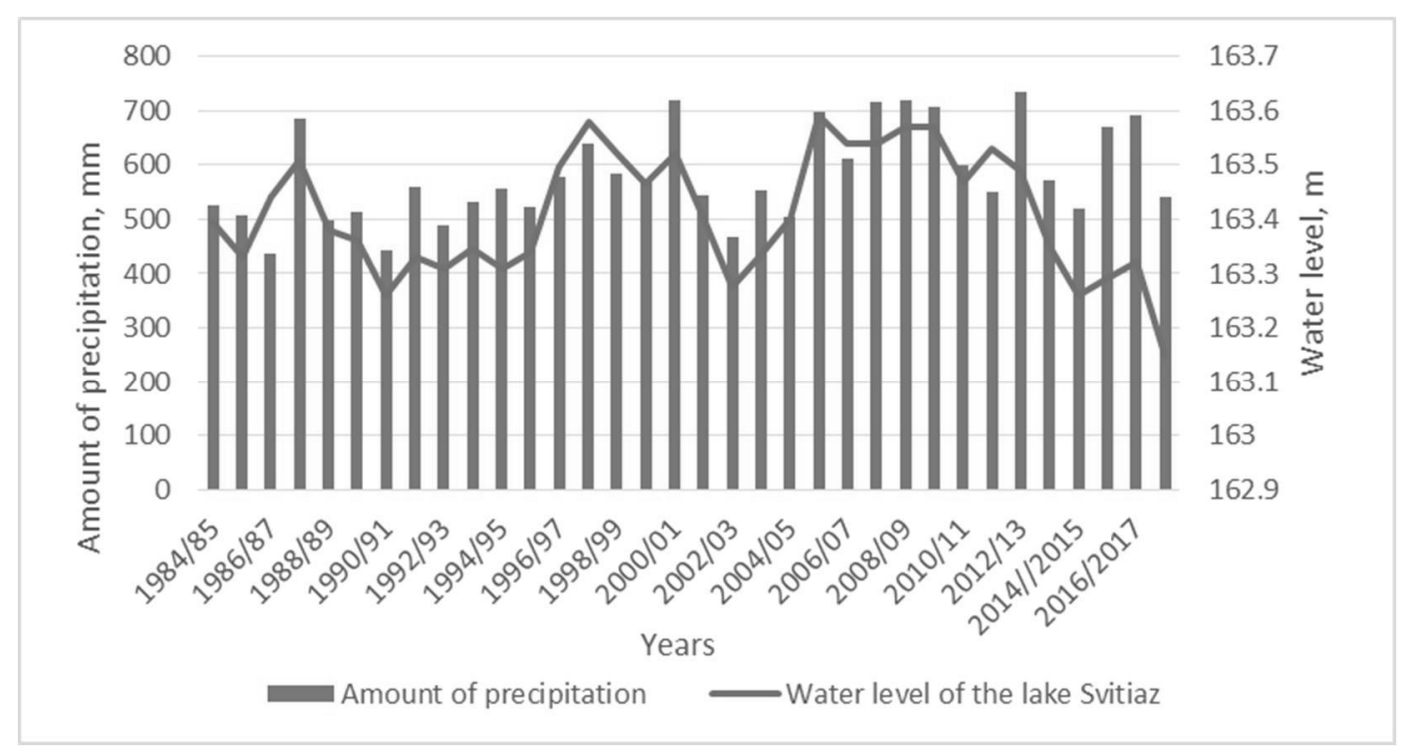

Fig. 5. Dependence between precipitation in 1985-2017 and the water level in Lake Svitiaz with a shift of 1 year

The correlation coefficients between the water level in the Lake Svitiaz, the air temperature and humidity, the amount of precipitation and their combination for the period of 2006-2019 have been calculated. The results are presented in the Table1. The average values of the correlation coefficients are:

- Between the air humidity and the water level $(\mathrm{H}+\mathrm{WL})-$ - 0.62;

- Between the air temperature and the water level $(\mathrm{T}+\mathrm{WL})-+0.28$;

- Between the amount of precipitation and the water level $(\mathrm{P}+\mathrm{WL})-+0.09$;
- Between the air humidity, the amount of precipitation and water level $(\mathrm{H}, \mathrm{P}+\mathrm{WL})-+0.67$;

- Between the air humidity, air temperature and the water level $(\mathrm{H}, \mathrm{T}+\mathrm{WL})-+0.76$;

- Between the air humidity, air temperature, the amount of precipitation and water level $(\mathrm{H}, \mathrm{T}, \mathrm{P}+\mathrm{WL})-$ $+0,80$.

The correlation coefficients between the amount of precipitation, the temperature, and the surface water level for different periods of 2006-2019 were also calculated. The results confirm the preliminary conclusions. The average value of the correlation coefficient between the 
amount of precipitation and the water level in Lake Svitiaz in spring is +0.24 , in summer and autumn, it is 0 . The average value of the correlation coefficient between the air temperature and the water level in spring and autumn, respectively, is 0.50 and 0.56 , and in summer 0.46 .

\section{Correlation coefficient between the air temperature, air humidity, the amount of precipitation and change in the water level of Lake Svitiaz}

\begin{tabular}{|c|c|c|c|c|c|c|}
\hline & $(\mathrm{H}+\mathrm{WL})$ & $(\mathrm{T}+\mathrm{WL})$ & $(\mathrm{P}+\mathrm{WL})$ & $(\mathrm{H}, \mathrm{P}+\mathrm{WL})$ & $(\mathrm{H}, \mathrm{T}+\mathrm{WL})$ & $(\mathrm{H}, \mathrm{T}, \mathrm{P}+\mathrm{WL})$ \\
\hline 2006 & -0.36 & 0.69 & 0.05 & 0.37 & 0.7 & 0.75 \\
\hline 2007 & -0.87 & 0.55 & 0.30 & 0.88 & 0.88 & 0.88 \\
\hline 2008 & -0.78 & 0.27 & 0.19 & 0.79 & 0.86 & 0.88 \\
\hline 2009 & -0.82 & 0.50 & 0.29 & 0.85 & 0.82 & 0.86 \\
\hline 2010 & -0.59 & 0.16 & -0.25 & 0.61 & 0.65 & 0.67 \\
\hline 2011 & -0.70 & 0.27 & 0.16 & 0.8 & 0.71 & 0.86 \\
\hline 2012 & -0.58 & -0.02 & -0.13 & 0.62 & 0.76 & 0.77 \\
\hline 2013 & -0.75 & 0.80 & 0.43 & 0.84 & 0.87 & 0.93 \\
\hline 2014 & -0.67 & 0.29 & 0.42 & 0.7 & 0.7 & 0.76 \\
\hline 2015 & -0.20 & -0.17 & -0.31 & 0.31 & 0.61 & 0.62 \\
\hline 2016 & -0.86 & 0.55 & 0.30 & 0.89 & 0.91 & 0.95 \\
\hline 2017 & -0.77 & 0.28 & -0.10 & 0.78 & 0.85 & 0.86 \\
\hline 2018 & -0.67 & 0.08 & 0.15 & 0.68 & 0.79 & 0.87 \\
\hline 2019 & -0.12 & -0.27 & -0.19 & 0.2 & 0.58 & 0.59 \\
\hline Average & $\mathbf{- 0 . 6 2}$ & $\mathbf{0 . 2 8}$ & $\mathbf{0 . 0 9}$ & $\mathbf{0 . 6 7}$ & $\mathbf{0 . 7 6}$ & $\mathbf{0 . 8 0}$ \\
\hline
\end{tabular}

\section{Conclusions}

Analyzing the results of the interactions between the fluctuations in the water level and the air temperature, humidity and the amount of precipitation on Lake Svitiaz, the following conclusions can be made:

- Low correlation coefficients indicate that the amount of precipitation does not affect the water level. Rather, last year's rainfall has a greater impact on the change in water level.

- The annual temperature variation is shifted relative to the change in the water level by an average of 2-3 months.

- The meteorological factors in 2010, 2015, and 2019 affected the water level inconsiderably. The reason is the other natural factors, such as, for example, solar activity or anthropogenic factors. But this question requires further research.

- Significantly larger correlation coefficients are observed when taking into account the total effect of the air humidity and precipitation or the humidity and the temperature on the change in the water level.

- The amount of precipitation, together with the air temperature and humidity, have maximum correlation values and affect the water level.

- The results of the study can be used to predict the seasonal fluctuations in the water level of Shatsk Lakes, depending on the meteorological factors and to assess the impact of technogenic factors, such as the
Khotyslavsk deposit, on the changes in the level of the lake water.

\section{References}

[1] Khomik N.: Ahrarna nauka, Kyiv 2013. (in Ukrainian)

[2] Zuzuk F.: Pryroda Zakhid. Polissia, prylehloho do Khotyslavskoho karieru Bilorusi, PP Ivaniuk V. P., Lutsk 2014. (in Ukrainian)

[3] Mateichyk V., Yurchuk P., Khomik N. ta in.: Litopys Pryrody, Svitiaz, 2019, 31. (in Ukrainian)

[4] Pohrebennyk V.: Hidroekoloh. doslidzhennia Shatskykh ozer (metody, zasoby, rezultaty). Spolom, Lviv, 2008. (in Ukrainian)

[5] Ilin L.: Limnokompleksy Ukrainskoho Polissia. Vezha, Lutsk 2008.

[6] Diatel O.: Melioratsiia i vodne hospodarstvo, 2017, 1106 (2), 58. (in Ukrainian)

[7] Karpenko N.: Visn. Lviv. Univers., 1996, 20, 59. (in Ukrainian)

[8] Mokryi V.: Pryroda Zakhidnoho Polissia ta prylehlykh terytorii, 2012, 9, 284 (in Ukrainian)

[9] Kutovyi S.: Naukov. visn. Volynskoho derzhavnoho univers. im. Lesi Ukrainky, 2007, 11 (1), 91. (in Ukrainian)

[10] Moroz O., Korliatovych T., Pokotylo I., Yamelynets S.: Visn. Heod. ta Kart., 2015, 5-6, 21. (in Ukrainian)

[11] Moroz O., Tartachynska Z., Pokotylo I., Korliatovych T.: Pryroda Zakhid. Polissia ta prylehlykh terytorii, 2017, 14 (1), 33. (in Ukrainian)

[12] Korliatovych T.: Geoforum-2016, Ukraine, Lviv Briukhovychi - Yavoriv, 32. (in Ukrainian) 